\title{
INVESTIGATION OF THE RELATIVE CONTRIBUTION OF GENETICS AND

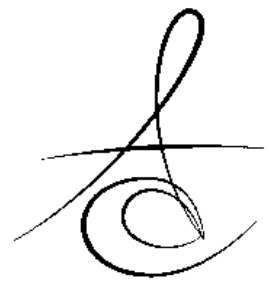 ENVIRONMENT ON MANDIBULAR MORPHOLOGY WITH THE CLASSICAL TWIN METHOD \\ GENETİK VE ÇEVRENİN MANDİBULAR MORFOLOJİYE KATKISININ KLASİK İKİZ YÖNTEMİ İLE ARAŞTIRILMASI \\ Dr. Öğr. Üyesi Damla TORUL* \\ Doç. Dr. Mehmet Melih ÖMEZLï \\ Arş. Gör. Dt. Mustafa AY*
}

Makale Kodu/Article code: 4445

Makale Gönderilme tarihi; 17.06 .2020

Kabul Tarihi: 21.10 .2020

DOI : $10.17567 /$ ataunidfd.814066
Damla Torul: ORCID ID: 00000000-0003-2323-606X

M. Melih Ömezli: ORCID ID: 00000000-0002-6606-6593

Mustafa Ay: ORCID ID: 00000000-0003-3589-1889

\section{ABSTRACT}

Aim: The purpose of this study was to explore the contribution of the genetics and the environment on the mandibular morphology of the Turkish twins.

Materials and Methods: This retrospective study conducted with the archival records of the twins who have applied between 2012 and 2018.-Condylar height, ramus height, gonial angle, intercondylar distance and intergonial distance were measured on the panoramic radiographs with computer software. The correlations between the monozygotic (MZ) and dizygotic (DZ) twins, and heritability estimates were evaluated.

Results: Moderate to high heritability observed in condylar height, ramus height, intercondylar distance and left gonial angle. Low heritability observed in intergonial distance and right gonial angle. Similar intra-pair correlations were found within the MZ and DZ male and female twin pairs for the measured parameters. However, no significant correlations observed within the DZ opposite sex twins. No significant difference also observed within the MZ male and female twin pairs in terms of the measured parameters except the significant difference in right ramus height of male MZ twins.

Conclusion: Horizontal parameters were found to be more susceptible to environmental factors than vertical ones. Gender was found to be caused similar variability in the measured parameters. Beside the results of the present study, it should be considered that the heritability is a concept that related with population rather than an individual, it would not be correct to reach definitive conclusions regarding the prevention of the disruptions, and prognosis of the treatments. Thus, the results should be interpreted cautiously when they are transformed into the clinical applications.

Keywords: Heritability, twin study, mandible

öz

Amaç: Bu çalıșmanın amacı, genetik ve çevrenin, Türk ikizlerinin mandibular morfolojisine katkısını araștırmaktır.

Gereç ve Yöntem: Bu retrospektif çalışma 2012 ve 2018 yılları arasında başvuruda bulunan ikizlerin arşiv kayıtları ile yapılmıştır. Panoramik radyografilerde bilgisayar yazııımı ile kondiler yükseklik, ramus yüksekliği, gonial açı, interkondiler mesafe ve intergonial mesafe ölçülmüştür. Monozigotik (MZ) ve dizigotik (DZ) ikizler arasındaki ilişki ve kalıtım derecesi tahminleri değerlendirilmiştir.

Bulgular: Orta ila yüksek derecede kalıtım etkisi kondiler yükseklik, ramus yüksekliği, interkondiler mesafe ve sol gonial açı parametrelerinde gözlendi. İntergonial mesafe ve sağ gonial açıda ise düşük kalıtım etkisi tespit edildi. Ölçülen parametreler için MZ ve DZ erkek ve kadın ikiz çiftlerinde benzer korelasyonlar bulunmakla birlikte, DZ farklı cinsiyetteki ikizler arasında anlamlı bir ilişki gözlenmedi. MZ erkek ve kadın ikiz çiftlerinde, ölçülen parametreler açısından, erkek MZ ikizlerinin sağ ramus yüksekliğindeki anlamlı fark dışında, anlamlı bir fark gözlenmedi.

Sonuçlar: Yatay parametrelerin dikey olanlara göre çevresel faktörlere daha duyarlı olduğu bulunmuştur. Cinsiyetin ölçülen parametrelerde benzer değişkenliğe neden olduğu görülmüştür. Bu çalışmanın sonuçlarının yanı sıra, kalıtımın bir bireyden çok popülasyonla ilgili bir kavram olduğu, tedavi aksamalarının önlenmesi ve prognozu konusunda kesin sonuçlara varmanın doğru olmayacağı dikkate alınmalıdır. Bu nedenle sonuçlar klinik uygulamalara dönüştürülürken dikkatli yorumlanmalıdır.

Anahtar Sözcükler: Kalııım derecesi, ikiz çalışması, mandibula

\section{*Department of Oral and Maxillofacial Surgery, Faculty of Dentistry, Ordu University, Ordu.}

Kaynakça Bilgisi: Torul D, Ömezli MM, Ay M. Genetik ve çevrenin mandibular morfolojiye katkııının klasik ikiz yöntemi ile araștııılması. Atatürk Üniv Diş Hek Fak Derg 2021; 31: 77-82.

Citation Information: Torul D, Omezli MM, Ay M. Investigation of the relative contribution of genetics and environment on mandibular morphology with the classical twin method. J Dent Fac Atatürk Uni 2021; 31: 77-82. 


\section{INTRODUCTION}

The growth of mandible is a complex biological event which is known to occur in response to genetic and environmental effects. ${ }^{1,2,3}$ The contribution of the genetics to the morphology of the growing mandible pose clinical importance in terms of the growth modification, therapeutic interventions and estimation of the prognosis. ${ }^{4}$ Twin studies regarded as a powerful tool in the evaluation of the contribution of genetics and the environment on various traits or disorders in humans. Classical twin model based on the assumption that monozygotic (MZ) twins share all of their genes, while dizygotic (DZ) twins, share on half average of their genes. By comparing the differences within pairs of $M Z$ and $D Z$ twins, in the classical method genetic contribution on the variation of a trait or anomaly can be determined. ${ }^{2,5-9}$ The differences between $\mathrm{MZ}$ twin pairs are considered to be originated from the environmental differences, while those in DZ twin pairs considered to be originated from both genetic and environmental factors. ${ }^{10}$

Modification of the development of mandible is based on that the heritability and environment are both responsible for its ultimate morphology. Nevertheless, the exact genetic contribution to mandibular morphology not completely clarified. ${ }^{1,11}$ Therefore, the aim of this study was to explore the contribution of environment and genetics on mandibular morphology of Turkish twins.

\section{MATERIALS AND METHODS}

\section{Patients}

This retrospective study was conducted with the panoramic radiographs of the twins who have applied to the Oral and Maxillofacial Surgery Department of Ordu University, between 2012 and 2018. The study protocol was approved by the Ethics Committee of the Ordu University (No: 2019-28) and conducted in accordance with the ethical standards in the Helsinki Declaration of 1964 and its subsequent amendments.

Inclusion Criteria:

- Twins with complete demographic, and radiological data

- Twin pairs who were taken the panoramic film at the same day

- Twin pairs with high-quality radiographic images Exclusion Criteria:
- Twin pairs who have low-quality radiographic images that prevent the measurements

Zygosity of the twin pairs was determined based on responses to a standard zygosity questionnaire ${ }^{12}$, sex and blood groups.

\section{Radiography}

The archive was scanned through the Turcasoft software (Turcasoft Dent, Samsun, Turkey) and the patients' panoramic films were reached. All panoramic radiographs had obtained by means of the Kodak 8000C Digital Panoramic System (Kodak Dental Systems, Rochester, NY). All measurements were performed by the same researcher using Turcasoft software. Radiographic measurements made separately from both sides in all patients by the same researcher. The researcher reviewed the radiographs on two separate sessions, one week apart. Intraobserver reliability was determined by comparing the first and second measurements. The average of the calculations was accepted as the value of the parameter. The horizontal, vertical and angular measurements on panoramic radiograph were shown in Figure 1.

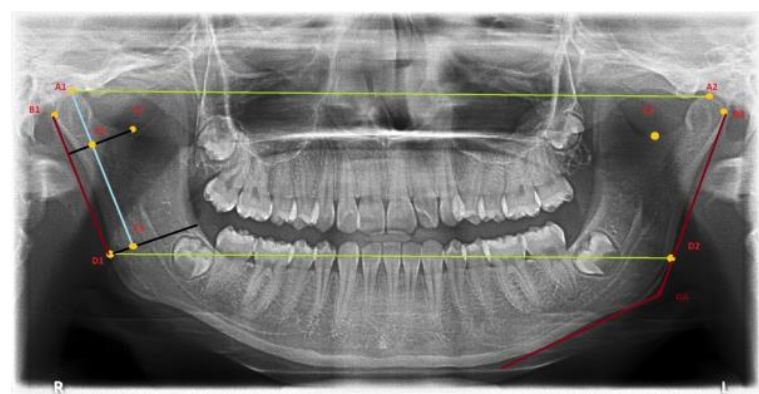

Figure 1. Panoramic film showing mandibular measurements.

$A_{1}, A_{2}$ : Most superior point of the condylar head

$B_{1}, B_{2}$ : Most outer point on the posterior border of condylar head

$\mathrm{C}_{1}, \mathrm{C}_{2}$ :-Most inferior part of the sigmoid incisura

$D_{1}, D_{2}$ : A point on the bony contour determined by bisecting the gonial angle

$\mathrm{A}_{1}-\mathrm{E}_{1}$ line: Condylar height

$A_{1}-f_{1}$ line: Ramus height

$\mathrm{A}_{1}-\mathrm{A}_{2}$ line: Intercondylar distance

$D_{1}-D_{2}$ line: Intergonial distance

GA (Gonial angle): The angle between the tangential line of the posterior border of the mandibular ramus and the lower border of the mandibular body

\section{Statistical analysis}

Statistical analyses were performed by using the IBM SPSS Statistics for Windows software (version 23.0, IBM Corp, Chicago, USA). Data were represented as mean (SD) and median (Min-Max). Normality of the data assess by the Kolmogorov Smirnov test. Pearson or Spearman correlations 
performed to explore the correlation in the vertical, horizontal and angular measurements within the twin pairs. Paired $t$ test or Wilcoxon test was used to compare the difference within the MZ male and female twins. To estimate the heritability of the measured parameters, Falconer's formula of heritability was applied. Narrow-sense heritability-additive genetic $\left(h^{2}\right)$, shared environmental $\left(c^{2}\right)$ and non-shared environmental $\left(e^{2}\right)$ variance calculated with the formulas as follows; $h^{2}=2\left(r_{M Z}-r_{D Z}\right), c^{2}=2 r_{D z}-r_{M z}, e^{2}$ $=1-r_{\text {Mz }}$. The intra-observer reliability was evaluated by comparing the measurements of the researcher at the first and the second sessions with the intraclass correlation coefficient (ICC). All tests were two-tailed and were based on a 0.05 were significance level.

\section{RESULTS}

This study consists of 70 pairs of Turkish twins. 20 of the twins were MZ while 50 of them DZ. The demographic data of the twins showed in Table 1.
Statistically significant correlations were found between MZ twin-pairs in terms of measurements except for intergonial distance. Significant correlations were also found between DZ twin-pairs in terms of measurements except for left condylar height and intercondylar distance. Descriptive of the measurements and heritability estimates among MZ and DZ twin pairs were shown in Table 2 and 3. Regarding gender significant correlations were observed in terms of left condyle and ramus height, gonial angles and intercondylar distance in female $M Z$ twin pairs while significant correlations found in terms of left condylar height, right-left ramus heights, gonial angles and intergonial distance in male MZ twin pairs (Figure 2). Female DZ twin pairs were showed significant correlations in right condylar height, gonial angles, intercondylar and intergonial distances. Male DZ twin pairs were showed significant correlations in left ramus height, gonial angles, intercondylar and intergonial distances. However, opposite-sex twin pairs did not show significant correlations in any of the measure-

Table 1. Demographic characteristics of the sample

\begin{tabular}{lcc}
\hline & MZ & DZ \\
\hline $\begin{array}{l}\text { Age } \\
(\text { Mean } \pm \text { SD }) /(\text { Min-Max })\end{array}$ & $19.55(12.89) /(9-54)$ & $12.28(3.65) /(6-24)$ \\
\hline Gender (\%) & $8(40 \%)$ & $19(26 \%)$ \\
Female & $12(60 \%)$ & $13(38 \%)$ \\
Male & - & $18(36 \%)$ \\
Opposite Sex & & \\
\hline
\end{tabular}

Table 2. Descriptive of the measured parameters

\begin{tabular}{|c|c|c|c|c|c|c|c|c|}
\hline \multirow{10}{*}{ 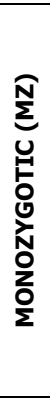 } & & & \multicolumn{2}{|r|}{$\mathrm{MZ}_{1}$} & \multicolumn{2}{|r|}{$\mathbf{M Z}_{2}$} & \multirow[b]{2}{*}{$r M Z$} & \multirow[b]{2}{*}{$\boldsymbol{p}$} \\
\hline & & & $M e a n \pm S D$ & $\begin{array}{c}\text { Median } \\
(\text { Min-Max) }\end{array}$ & $M e a n \pm S D$ & $\begin{array}{c}\text { Median } \\
(\text { Min-Max) }\end{array}$ & & \\
\hline & \multirow{2}{*}{ Condylar height } & $\mathrm{R}$ & $1.88 \pm 0.32$ & $1.80(1.50-2.88)$ & $1.81 \pm 0.19$ & $1.85(1.15-2.18)$ & 0.568 & $0.009 *$ \\
\hline & & $\mathrm{L}$ & $1.81 \pm 0.25$ & $1.85(1.15-2.18)$ & $1.79 \pm 0.25$ & $1.76(1.18-2.27)$ & 0.797 & $<0.001^{*}$ \\
\hline & \multirow{2}{*}{ Ramus height } & $\mathrm{R}$ & $2.75 \pm 0.44$ & $2.73(2.26-3.72)$ & $2.84 \pm 0.41$ & $2.74(2.18-4.04)$ & 0.808 & $<0.001^{*}$ \\
\hline & & $\mathrm{L}$ & $2.74 \pm 0.48$ & $2.73(1.95-4.14)$ & $2.84 \pm 0.39$ & $2.80(2.18-3.72)$ & 0.858 & $<0.001^{*}$ \\
\hline & \multirow{2}{*}{ Gonial angle } & $\mathrm{R}$ & $127.66 \pm 22.72$ & $122.44(107.69-220.51)$ & $122.62 \pm 7.41$ & $122.58(108.53-137.66)$ & 0.528 & $0.017 *$ \\
\hline & & $\mathrm{L}$ & $124.44 \pm 6.78$ & $124.75(112.44-139.71)$ & $124.57 \pm 7.73$ & $125.19(105.78-135.66)$ & 0.747 & $<0.001^{*}$ \\
\hline & \multicolumn{2}{|c|}{ Intercondylar distance } & $17.77 \pm 1.9$ & $17.55(14.86-22.26)$ & $17.98 \pm 1.75$ & $18.48(14.58-20.62)$ & 0.511 & $0.021 *$ \\
\hline & \multicolumn{2}{|c|}{ Intergonial distance } & $16.06 \pm 1.37$ & $15.91(14.41-19.53)$ & $16.41 \pm 1.5$ & $16.46(13.61-19.56)$ & 0.402 & 0.079 \\
\hline \multirow{10}{*}{ 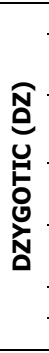 } & & & & $\mathrm{DZ}_{1}$ & & $\mathbf{D Z}_{2}$ & & \\
\hline & & & $M e a n \pm S D$ & $\begin{array}{c}\text { Median } \\
\text { (Min-Max) }\end{array}$ & $M e a n \pm S D$ & $\begin{array}{c}\text { Median } \\
(\text { Min-Max }) \\
\end{array}$ & $r D z$ & $p$ \\
\hline & \multirow{2}{*}{ Condylar height } & $\mathrm{R}$ & $1.81 \pm 0.20$ & $1.81(1.37-2.40)$ & $1.80 \pm 0.21$ & $1.84(1.20-2.31)$ & 0.299 & $0.035^{*}$ \\
\hline & & $\mathrm{L}$ & $1.85 \pm 0.33$ & $1.80(1.34-3.32)$ & $1.84 \pm 0.30$ & $1.84(1.17-2.84)$ & 0.114 & 0.433 \\
\hline & \multirow{2}{*}{ Ramus height } & $\mathrm{R}$ & $2.51 \pm 0.39$ & $2.49(1.31-3.82)$ & $1.80 \pm 0.21$ & $1.84(1.20-2.31)$ & 0.295 & $0.038^{*}$ \\
\hline & & $\mathrm{L}$ & $2.57 \pm 0.35$ & $2.53(1.85-3.87)$ & $2.53 \pm 0.34$ & $2.45(1.87-3.43)$ & 0.585 & $<0.001^{*}$ \\
\hline & \multirow{2}{*}{ Gonial angle } & $\mathrm{R}$ & $124.56 \pm 7.46$ & $124.84(105.76-137.35)$ & $125.46 \pm 10.66$ & $126.64(67.55-143.25)$ & 0.459 & $0.001^{*}$ \\
\hline & & $\mathrm{L}$ & $126.67 \pm 6.91$ & $128.64(110.85-139.20)$ & $127.54 \pm 6.36$ & $126.75(114.38-147.64)$ & 0.420 & $0.002^{*}$ \\
\hline & \multicolumn{2}{|c|}{ Intercondylar distance } & $17.47 \pm 1.75$ & $17.18(13.36-21.87)$ & $18.97 \pm 11.44$ & $17.24(13.83-97.42)$ & 0.272 & 0.056 \\
\hline & \multicolumn{2}{|c|}{ Intergonial distance } & $15.67 \pm 1.91$ & $15.36(10.13-21.11)$ & $15.56 \pm 1.60$ & $15.39(10.62-18.67)$ & 0.575 & $<0.001^{*}$ \\
\hline
\end{tabular}

R: Right, L: Left, SD: Standard deviation, r: correlation coefficient, *: significant (Pearson or Spearman correlation) 
ments (Figure 3). No significant difference observed within the MZ male and female twin pairs in terms of the measured parameters except the significant difference in right ramus height of male $M Z$ twins $(p<0.001)$. The ICC for the first and second measurements were between 0.976-0.998 (IC 0.958-0.999) for the measurements of DZ twins and 0.978-0.999 (IC 0.944-1) for the measurements of MZ twins.

Table 3. Heritability estimates for variables

\begin{tabular}{|l|c|c|c|}
\hline \multicolumn{1}{|c|}{ Phenotype } & $\boldsymbol{h}^{\mathbf{2}}$ & $\boldsymbol{c}^{\mathbf{2}}$ & $\boldsymbol{e}^{\mathbf{2}}$ \\
\hline Condylar height_R & 0.53 & 0.03 & 0.43 \\
\hline Condylar height_L & 1.36 & -0.56 & 0.20 \\
\hline Ramus height_R & 1.02 & -0.21 & 0.19 \\
\hline Ramus height_L & 0.54 & 0.31 & 0.14 \\
\hline Gonial angle_R & 0.13 & 0,39 & 0.47 \\
\hline Gonial angle_L & 0.65 & 0.09 & 0.25 \\
\hline Intercondylar distance & 0.47 & 0.03 & 0.48 \\
\hline Intergonial distance & -0.34 & 0.74 & 0.59 \\
\hline
\end{tabular}

R: Right, L: Left
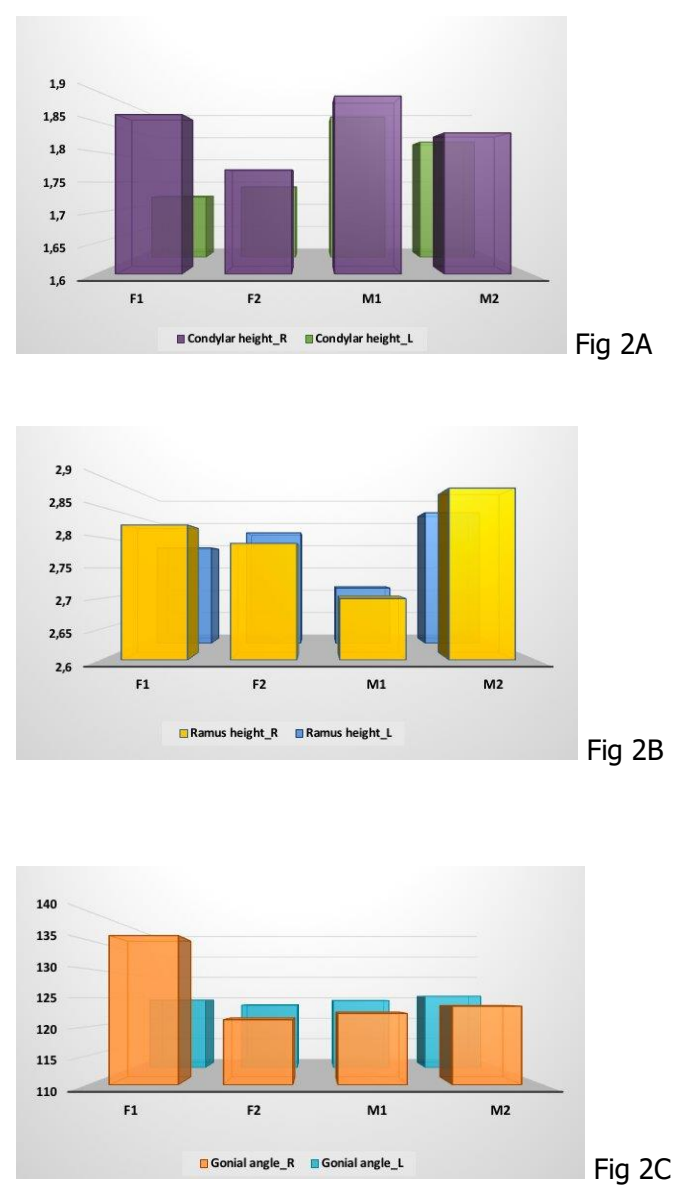

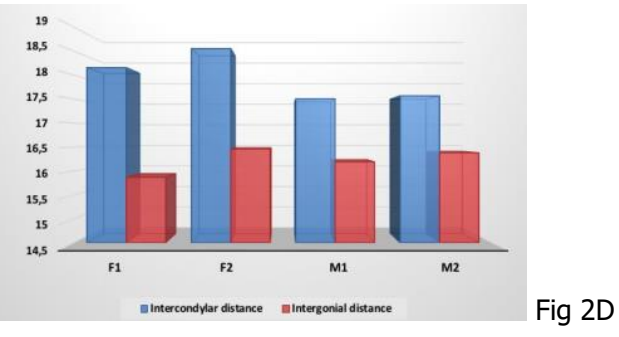

Figure 2: A. Condylar height (mm), B. Ramus height ( $\mathrm{mm})$, C. Gonial angles, D. Intercondylar and intergonial distances(mm) among gender of $M Z$ twins
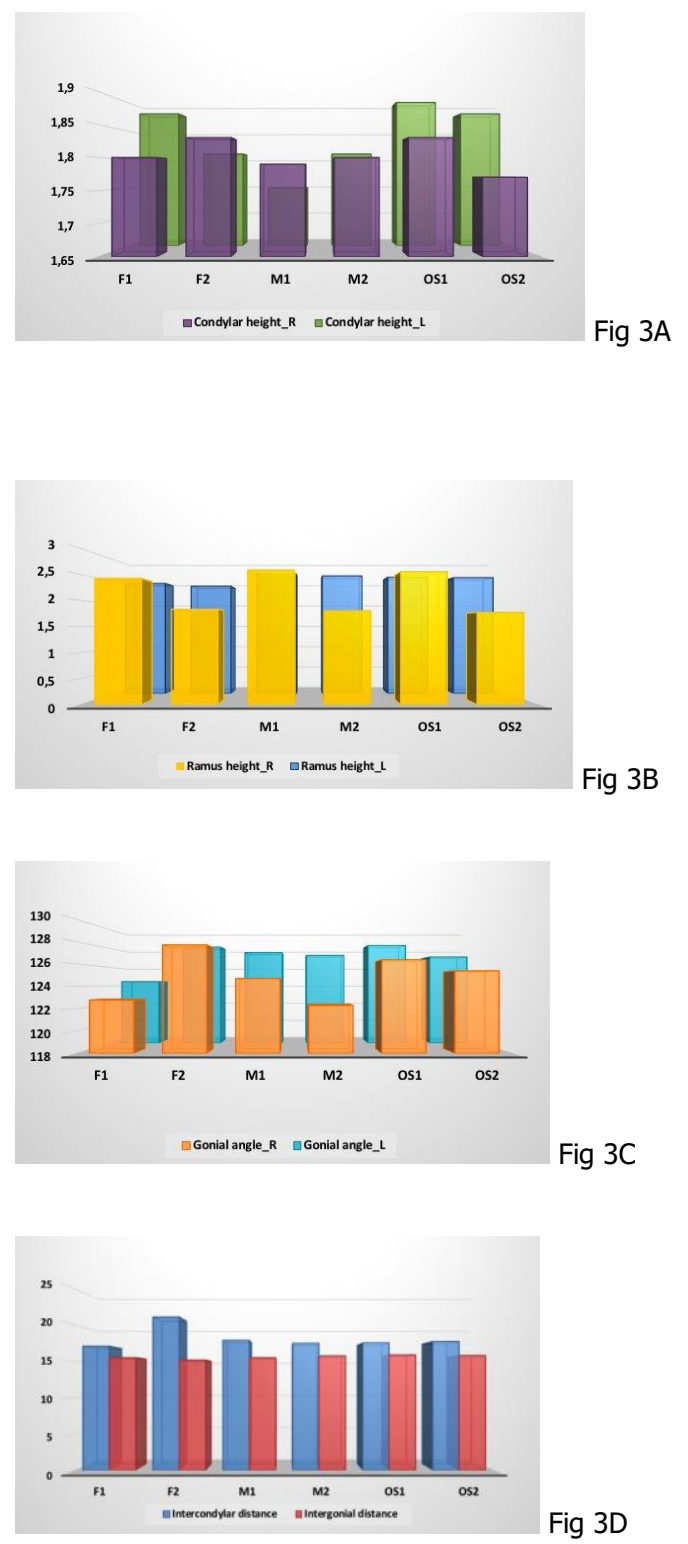

Figure 3:A. Condylar height $(\mathrm{mm})$, B. Ramus height $(\mathrm{mm})$, C. Gonial angles, D. Intercondylar and intergonial distances$(\mathrm{mm})$ among gender of DZ twins 


\section{DISCUSSION}

The final phenotype of the craniofacial morphology, represents complex interaction between genetics and environmental factors. ${ }^{1,10}$ Studies that explore the exact role of the genetics and environmental components of this interaction on mandibular morphology reported different results regarding morphological parts responsible for the size and form of the mandible. In the study of Sidlauskaset al. ${ }^{1}$ that conducted on 141 same-gender adult twin pairs high heritability values reported for the gonial and mandibular arc angles. In the cross-sectional twin study of Amini et al. ${ }^{10}$ gonial angle values showed high heritability. Similarly, Manfredi et al. ${ }^{12}$ found high heritability for the gonial angle. However, a moderate heritability was also reported by Carels et al. ${ }^{9}$ for the gonial angle. In this study we found high heritability for the left gonial angle while low heritability values observed for the right gonial angle. This result may be originated from the different amount of the contribution of the genetic, environmental, and epigenetic factors on these parameters or may be due to the skewness of the data regarding zygosity.

Regarding linear variables, it is reported that the horizontal parameters are majorly determined by genetic factors rather than the vertical ones. ${ }^{1,2}$ Some researchers however were insisted on the opposite.9, 10,14 Sidlauskas et al. ${ }^{3}$ reported in their cephalometric study on $90 \mathrm{MZ}$ twin pairs that total mandibular and corpus lengths showed the highest intra-pair correlation. In another study of the same authors it is reported that mandibular length, ramus width and height showed low genetic determination. ${ }^{1}$ High heritability values for mandibular length were found in the studies of Dudas and Sassouni. ${ }^{15}$ and Carels et al. ${ }^{9}$ However, Nakataet al. ${ }^{8}$ and Amini et al. ${ }^{10}$ observed low and moderate heritability for mandibular length, and ramus height, respectively. We found that ramus height and condyle height were showed higher heritability, than the intercondylar and intergonial distances. Regarding the effect of gender on mandibular morphology Šidlauskas et al. ${ }^{4}$ found that females showed significant differences in terms of mandibular length within MZ twin pairs. They suggested that this may indicate the role of hormonal influence on mandibular development. But, in our study similar correlations were found within the MZ twin pairs for the measured parameters between males and females. These differences among the results of the studies may be originated from the differences in the determination of zygosity, size of the sample, maturity stage of the patient, radiological evaluation methods and statistical methods used. Thus, the results of twin studies should be interpreted with caution. Also, further prospective studies should be conducted with larger samples and more clinical/radiological parameters to the exact reason behind the contribution of the genetic, epigenetic and environmental factors on mandibular morphology.

The radiologic method used is an important factor that determines the accuracy of the evaluations. Panoramic radiography is usually the first imaging modality of choice to overview the teeth and jaws with low radiation exposure. It is a practical, fast and safe method when studying with large number of samples and has favorable cost-benefit relationship. ${ }^{16-19}$ Also, the repetition of the measurements is acceptable when the position of the patient's head positioned correctly. Thus, linear measurements have been performed, such as alveolar height, and condylar dimensions by this technique. ${ }^{17,20}$ Although in the majority of the studies cephalometric radiographs utilized for the evaluation of the mandibular morphology, because of the retrospective design of our study and usability of the panoramic radiography for performing linear measurements we used digital panoramic radiographs of the twins that had obtained at the same time.

There are potential limitations. It is reported that the contribution of the genetic and environment changes with the age. ${ }^{6,}{ }^{21}$ Also, the precise evaluation of the genetic contribution is difficult with narrow samples. ${ }^{10}$ Thus, the design of the present study did not assess the genetic contribution with high precision. As in other twin studies difficulty in establishing zygosity is another limitation. ${ }^{6}$ In that the exact genetic contribution on mandibular morphology can be determined when the growth is completed, the maturity of the sample is also another problem. ${ }^{1}$

\section{CONCLUSIONS}

Despite the limitations, it can be concluded that moderate to high heritability observed in condylar and ramus height, intercondylar distance and left gonial angle. Low heritability observed in the intergonial distance and right gonial angle. The female $M Z$ twin pairs showed similar variability in the measurements when compared to the male MZ twin pairs. Therefore, no hormonal influence seems to be present. Beside the results of the present study, it should be considered that the heritability is a concept that 
related with population rather than an individual, it would not be correct to reach definitive conclusions regarding the prevention of the disruptions, and prognosis of the treatments. Thus, the results should be interpreted cautiously when they are transformed into the clinical applications.

Acknowledgements:

This study was not funded by any organization.

Conflict of Interest:

The authors declare that they have no conflict of interest.

\section{REFERENCES}

1. Sidlauskas M, Salomskiene L, Andriuskeviciute I, et al. Heritability of mandibular cephalometric variables in twins with completed craniofacial growth. Eur J Orthod 2016;38:493-502.

2. Ceylan, İ. Alt Çene Büyümesinin bir göstergesi olarak simfiz ve birinci servikal vertebranin morfolojisinin değerlendirilmesi. Atatürk Üniv Diş Hek Fak Derg 1995;5:23-30.

3. Kim E, Sung J, Song YM, et al. Heritability of facial skeletal and dental characteristics of monozygotic and dizygotic twins using cephalometric analysis and falconer's method. J Craniofac Surg 2018;29: 274-9.

4. Sidlauskas M, Salomskiene L, Andriuskeviciute I, Sidlauskiene M, Labanauskas Z, Sidlauskas A. Mandibular morphology in monozygotic twins: a cephalometric study. Stomatologija 2014;16:137-43.

5. Lundstrom A. Nature versus nurture in dento-facial variation. Eur J Orthod 1984;6(2):77-91.

6. Peng J, Deng H, Cao C, Ishikawa M. Craniofacial morphology in Chinese female twins: a semilongitudinal cephalometric study. Eur J Orthod 2005; 27:556-61.

7. Dunn GF, Green U, Cunat JJ. Relationships between variation of mandibular morphology and variation of nasopharyngeal airway size in monozygotic twins. Angle Orthod 1973;43:129-35.

8. Nakata M, Yu PL, Davis B, Nance WE. Genetic determinants of cranio-facial morphology: a twin study. Ann Hum Genet 1974;37:431-43.

9. Carels C, Van Cauwenberghe N, Savoye I, et al. A quantitative genetic study of cephalometric variables in twins. Clin Orthod Res 2001;4:130-40.

10. Amini F, Borzabadi-Farahani A. Heritability of dental and skeletal cephalometric variables in monozygous and dizygous Iranian twins. orthodontic waves 2009;68:72-9.

11. Naini FB, Moss JP. Three-dimensional assessment of the relative contribution of genetics and environment to various facial parameters with the twin method. Am J Orthod Dentofacial Orthop 2004;126:655-65.

12. Kaprio J, Sarna S, Koskenvuo M, Rantasalo I. The Finnish Twin Registry: formation and compilation, questionnaire study, zygosity determination procedures, and research program. Prog Clin Biol Res 1978;24:179-84.

13. Manfredi C, Martina R, Grossi GB, Giuliani M. Heritability of 39 orthodontic cephalometric parameters on MZ, DZ twins and MN-paired singletons. Am J Orthod Dentofacial Orthop 1997; 111: 44-51.

14. Lundstrom A, McWilliam JS. A comparison of vertical and horizontal cephalometric variables with regard to heritability. Eur J Orthod 1987;9:104-8.

15. Dudas M, Sassouni V. The hereditary components of mandibular growth, a longitudinal twin study. Angle Orthod 1973;43:314-22.

16. Back K, Ahlqwist M, Hakeberg M, Dahlstrom L. Occurrence of signs of osteoarthritis/arthrosis in the temporomandibular joint on panoramic radiographs in Swedish women. Community Dent Oral Epidemiol 2017;45:478-84.

17. Godavarthi AS, Sajjan MC, Raju AV, Rajeshkumar P, Premalatha A, Chava N. Correlation of condylar guidance determined by panoramic radiographs to one determined by conventional methods. J Int Oral Health 2015;7:123-8.

18. Van Elslande DC, Russett SJ, Major PW, Flores-Mir C. Mandibular asymmetry diagnosis with panoramic imaging. Am J Orthod Dentofacial Orthop 2008;134:183-92.

19. Larheim TA, Svanaes DB. Reproducibility of rotational panoramic radiography: mandibular linear dimensions and angles. Am J Orthod Dentofacial Orthop 1986;90:45-51.

20. Sadat-Khonsari R, Fenske C, Behfar L, Bauss O. Panoramic radiography: effects of head alignment on the vertical dimension of the mandibular ramus and condyle region. Eur J Orthod 2012;34:164-9.

21. Harris EF, Johnson MG. Heritability of craniometric and occlusal variables: a longitudinal sib analysis. Am J Orthod Dentofacial Orthop 1991;99:258-68.
Sorumlu Yazarın Yazışma Adresi
Damla TORUL, DDS PhD
Ordu University, Faculty of Dentistry,
Department of Oral and Maxillofacial Surgery,
Altınordu/Ordu, Turkey-52200
Tel: +90 4522121286
Email: damlatorul@gmail.com 